\section{Ravindra Hewa Kuruppuge}

kuruppuge@yahoo.com

University of Peradeniya | Sri Lanka

\section{Athula Ekanayake}

athulae@gmail.com

University of Peradeniya | Sri Lanka

\title{
An Analytical Model to Explain the Governance of Family Owned Businesses
}

\section{Abstract:}

The governance of businesses tends to vary depending on the ownership, i.e., the private sector vs. the public sector, or the industry, for example, banking vs. non-banking, and many more. This paper aims to develop an analytical model in explaining the governance of family owned businesses more specifically. It argues that because of the family ownership and the family management, family businesses require a particular attention. Also, because family businesses appear to set non-financial goals in addition to financial goals the governance of family businesses cannot be equally treated as those of other firms in the private sector. Given the less developed nature of the capital markets in the developing countries such as Sri Lanka, family businesses play a significant role in the economic development of such countries. Nevertheless, family businesses face significant survival challenges, as they are likely to promote those who have family ties into management positions than the professional managers. By reviewing the existing literature critically, this paper identifies the variables, namely family power (i.e., ownership and management), experience and cultural 
factors, which influence the accomplishment of financial and non-financial goals of family owned businesses, and develops an analytical model to explain their governance.

\section{Key words:}

family owned businesses, governance, family ownership, family involvement, analytical model.

\section{Introduction}

The majority of research studies on family business conducted during last couple of years have focused on their economic dominance (Chua et al., 1999; Habbershon et al., 2003). The purpose of this paper is to develop an analytical model to explain the governance of family owned businesses. The success of exploring family ownership and involvement in business mainly depends on the identification of family business as a separate type of business from non-family business. However, the existing literature suggests that it is difficult to establish sources of this uniqueness in comparative studies between family and non-family businesses. In identifying the uniqueness in family business based on prior research related to family businesses, family ownership and management in business appear to play a crucial role. Thus, this study argues that family businesses are comparatively different from non-family firms because family ownership and management play a significant role in shaping the success or failure of family businesses.

The rest of the paper is structured as follows. The next section attempts to identify family businesses more specifically. For this purpose, some definitions for family businesses given in the literature will be reviewed to identify their source of distinction. Following that the third section discusses different views of family involvement namely the general view of family business and the special view of family business. The next two sections respectively classify the family owned businesses and identify financial versus non financial goals of family owned businesses. In the penultimate sec- 
tion, a framework to explain the governance of family owned businesses is introduced. The final section provides concluding remarks of the paper.

\section{Family Owned Businesses}

Family businesses may require a particular attention in governance due to their unique features over non-family businesses. This section recognizes specific characteristics of family owned businesses and explains how they are different from non-family businesses. It will first discuss some of the definitions available in the literature on family businesses, and then identify the factors that distinguish family businesses from non-family businesses.

Although many scholars attempted to define family owned businesses there is no commonly accepted definition for universal application (Klein, Astrachan, \& Smyrnios, 2005). Among them the one by Gersick et al. (1997) appears to provide a comprehensive definition of family business. They have identified three factors for the difference between family and non-family businesses, namely the higher shareholding ratio or the portion of ownership holding by a particular family compared to non-family members of the business; the family member or relative within second degree relative is acting as the president or the general manager; and family members or close relatives occupy more than half of the board of directors. In this definition, the critical shareholding rights of family members are used as the key variable for identifying family business. Meantime, the key position in the business such as the Chairman or CEO is also considered.

All or part of the entrepreneurial management levels of an enterprise seems to be based on blood or relative relationship in a family owned business, and it has certain entrepreneurial ownership and control right. Following that, family business can be defined as an enterprise with ownership effectively controlled by one or more families. The extent to which a family can control a business depends on three aspects, namely family owner- 
ship, management involvement and willingness of succession (Chua et al., 1999; Habbershon et al., 2003). This definition suggests that characteristics such as family ownership, family management right, succession, family involvement, family shareholding structure and level of control by a family, make family businesses different from non-family businesses.

Nicholson (2008) points out that a family business consists of characteristics such as ownership and management right, succession and power transfer, and a team between relative and non-relative. Family members control the family business and thus the decisions regarding management rights are affected by family relationship (Gersick et al., 1997). Hence, unlike in the other businesses, family members possess most of the ownership and control rights in family businesses which are transferred between generations. For instance, elder members in the family will be replaced by the younger members in the family, i.e. family businesses have succession and power transfer characteristics.

Considering the definitions of the most recent contributions, there is a growing agreement among the researchers around two key ideas. First, family businesses are not homogeneous entities, but consist of different types (Sharma 2004; Chrisman, Chua, \& Sharma, 2005). Second, all family businesses have interaction of the business entity, the family unit, and its individual members (Habbershon \& Williams, 1999). Such interaction creates unique systematic conditions and constituencies that may enhance or diminish competitive advantage, and impact on performance outcomes of family business social system (Habbershon, Williams, \& MacMillan, 2003).

Habbershon et al. (2003) argue that the performance of family business is a function of 'familiness' which refers to the peculiar bundle of resources and capabilities resulting from the system interactions. They use the term 'familiness' to characterize those interactions between family members, the business and the community with the potential to create competitive advantage or disadvantage for the business that creates a uniqueness to family business. While this is a useful abbreviation for what makes family busi- 
nesses different from non-family businesses and their success or failure, as a concept it also provides a foundation of a theory for the family business.

Further to the views expressed from the point of view of ownership and management on the differences between family and non-family businesses, the literature suggests that customer and supplier point of views can also be used to distinguish these two types of businesses. For instance, family businesses tend to be more interested in building long-term relationships with customers and suppliers (Gomez-Mejia et al., 2001). Such actions have broadened the customer relationship and allow for a better knowledge of the client, while the personal, face-toface involvement between family members and customers can set connections, increase mutual understanding and boost loyalty (Miller et al., 2008). For example, Buckley (2006), in his study on consumer perceptions of Irish family businesses, found that respondents had positive shopping encounters with family businesses. Their findings also suggest that family businesses are perceived to be more trustworthy and expected to hold high levels of product knowledge and customer service.

Some other researchers have identified that family connection is an important feature in family business (e.g., Morck \& Yeung, 2004; Poza, 1995). This means that owners of family firms are more eager in sustaining the business because of the 'deep connections between the family and the business' which is not a feature for non-family businesses. Morck \& Yeung (2004) argue that family businesses merely want to take care of their own interests. Poza (1995) suggests that family businesses enjoy a competitive advantage among other things due to family interaction. It is clearly based on these findings that family businesses are influenced by the owning family. Goehler (1993) points out that family influence forms the family business different. "At the most basic level, what differentiates a family business from other profit seeking organizations is the family's influence on the decision making and operations of the firm" (Chrisman, Chua, \& Zahra, 2003). 
The analysis of the definitions of family businesses suggests that family businesses are comparatively different from non-family businesses. The important features of family businesses as stated in definitions over non-family businesses include family ownership, blood or relative relationship between the ownership and management, 'familiness', customer and supplier relationships and family connection. Next section discusses different views of family involvement.

\section{Different Views of Family Involvement in Businesses}

The existing body of literature has increasingly looked into 'family' as an explanatory concept to understand organizational behavior (Sharma, 2004). This growing body of literature can be used to identify key characteristics of family businesses. Those characteristics vary, firstly creating a differentiation between family and non-family businesses and secondly even within the family businesses. Most of such studies have given prominence to family involvement, and to anticipate how this may influence family businesses and how this involvement has become a significant factor of such businesses. The previous section reviewed the definitions of family owned businesses with a view of identifying family owned businesses separately from non-family businesses. This section discusses different aspects of family involvement that lead to identify family involvement as the significant character of family business in terms of differentiating family and non family businesses.

Family membership appears to be contextual and subjective. For instance, Habbershon et al. (2003) state that 'family' is in many ways utilized incorrectly with its affiliation of a nuclear unit or an extended family that includes individuals who are directly related in organizations, or may be extended to more distant relatives (Habbershon et al., 2003). Further, Stewart 
(2003) argues that it is more appropriate to talk about "kinship" rather than family businesses. Furthermore, Paredo (2003) extended this idea further, arguing that kin includes not only relations by blood and marriage but also can be included "spiritual" kin, based on characteristics such as birth place or identification with a common community. These different views of family involvement can be discussed in two ways: the general view of family businesses and the special view of family businesses in order to establish that family involvement is a major contributory factor among all other factors discussed above in relation to family businesses.

\section{General View of Family Involvement}

The discussion so far in this section leads to the conclusion that family involvement in the business is what makes the family business different from non-family business. Researchers argue that family involvement will lead to distinctive goals, behaviors, and performance outcomes within and outside the family business (Chrisman et al., 2005; Dyer, 2006). Further, several studies find that family firms are performing better than their counterparts simply because of family involvement in such businesses (e.g., Anderson \& Reeb, 2003).

However, some researchers argue that better performance in the family owned businesses is more likely due to the way family involvement and performance are measured in those studies (see Chrisman et al., 2010). More specifically, they reveal that family businesses have distinctive goals than non family businesses, and thus the performance of family businesses needs to be measured differently than that of non-family businesses. Moreover, some others argue that what is more important is not the definition of family businesses but how much the family is involved in the business that gives a clear difference between family and non-family businesses (Astrachan, Klein \& Smyrnios, 2002). Finally, the power of family in- 
volvement is likely to depend on the extent to which family can influence on the business (Chrisman et al., 2005).

Sharma (2004) outlines several variations of family involvement in family businesses. The first is the control of the family over voting or power and day-to-day management, i.e., the family's control over governance of the business. The next two variations are the depth and the breadth of family involvement in the business (Sharma, 2004). The former refers to the involvement of family members across generations. This is most commonly referred as leadership succession within the family. The latter refers to the number of family members in the business regardless of whether they are being paid or not. This may range from the unpaid labor of housewives undertaking small tasks for the business to most or all positions by family members within the business.

This general view of family involvement reviews one important aspect. It clearly emphasizes the family business as different type of business over non family business. Further, this review of family involvement explains that not all family businesses are equal in terms of family involvement. Nevertheless, it is evident that family involvement plays a significant role in family businesses.

\section{Special View of Family Involvement}

The special view of family involvement reviews the nature and the degree of family involvement in detail. Scant attention has been given to study the nature and the degree of the family involvement in businesses in the literature (Dharmadasa, 2009). Among few studies, some consider family involvement as a means of affecting the business, and analyze the relationship between the family's effect on the business and business performance. They appear to seek how the presence of family affects the performance of businesses. Astrachan et al., (2002) measure the effect of the family in terms of the fam- 
ily power, experience and cultural factors. This special view of family business is likely to remain with these three factors of family business, and provides a solid ground of significance of family involvement in the business.

The family power, experience and cultural factors seem to have many advantages in assessing family involvement in the family business due to its multi-dimensional perspective. The power of family members engaging in business concentrates on the areas of family's share in ownership, management, and governance (i.e., power sub-scale); the generation that owns, manages, and governs the business, and the number of family members within and outside the business context are explained by the experience factor (i.e., experience sub-scale) of family involvement. Finally, the cultural factor (i.e., culture sub-scale) is reviewed by the family's commitment to the business and the degree of similarity between family and business values (Astrachan et al., 2002). These sub-scales are important to understand the degreetowhichthefamilyisinvolvedinandthereforeinfluencesthebusiness.

Several studies have also investigated the effect of family involvement on business performance by using these three criteria to measure the degree of family involvement. The performance has been measured in such studies being financial related and managerial performance of businesses. Among the studies which have been carried out to investigate the former relationship, Jaskiewicz et al. (2005) find that greater family involvement (measured by the power sub-scale) is associated with better long-term performance of the companies share prices in German and Spanish. In a similar study, Alcaraz (2004) employs two methods to assess the family effect in Mexican family businesses: the three factors namely family power, experience and cultural factors, and the familial index. The familial index, which only includes the family's share in ownership and management, shows a weak positive relationship with satisfaction of financial performance. Ayranci (2009) also initially employed the three factors but later claimed that this scale, in its original form, was not appropriate for Turkish family businesses. Instead, he identified five criteria in the pilot survey 
to measure the family effect namely, contribution of the family to financial decisions; loyalty and harmony related to the business; effects of spouses; effects of successors; and effects of founders. This study finds a weak negative relationship between the family effect and the satisfaction with financial performance.

Few studies have been conducted to look into the relation of family involvement and managerial performance. For instance, Jaskiewicz et al. (2006) examines the relationships between the family effect, the behavioral patterns of top management teams and business performance in German family businesses. They reveal that the presence of family causes top managers to act similarly to the family members while maintaining a focus on the firm's performance. Further, Di Pofi (2003) analyzes the relationship between the family effect and managers' satisfaction with the financial performance of their business, using data from the 2002 American Family Business Survey. While the power sub-scale is omitted, the experience and culture sub-scales showed a positive relationship with the degree of satisfaction in this study. Furthermore, Dudaroglu (2008) investigates family firms in Turkey in the automotive supplies industry using the culture subscale as a means of assessing the family effect. Positive relationships were found among the family effect, business performance, and the behavioral integration of the top management team in this study.

Despite the importance of the family power, experience and cultural factors in measuring the degree of family involvement in businesses, there are drawbacks using this instrument in some cases, for example, single owner managed family businesses (Ayranci, 2009), incapability of measuring all dimension of family involvement, lack of organizational aspects in the measurement (Ayranci \& Semercioz, 2010). However, those who argue against these three factors believe that it is one approach among several other approaches to measure family involvement. For example, Chrisman et al. (2005) states that determining nature of business as family or non family in terms of family involvement is harder than it appears at first glance. 


\section{Classification of Family Owned Businesses}

The discussion so far indicates the complex nature of the family involvement in the governance of family businesses. In order to clarify matters related to family involvement researchers have attempted to divide family firms into different categories based on their characteristics. This classification assists to identify differences within the family businesses based on the degree of family members' involvement in ownership and management. The types of family business include pure family business, quasi family business, pan family business and mixed family business (Astrachan et al., 2002). Each type is described below.

(1) Pure Family business: The level of control by the family in the pure family businesses is 100 percent. For example, in pure family businesses, all the property rights and voting rights are controlled by the hands of the enterprise leader or his/her family members, meanwhile all the management positions in the enterprise are held by the blood relative members of the enterprise leader. All the property rights, management rights, management personnel and control rights of the enterprise are monopolized by the family. (2) Quasi family business: In this type of a family business, property rights, control rights and management positions are held by the family. The only difference is that members entering the enterprise include not only the blood relative of the enterprise leader but also the marriage relatives of the enterprise leader. At this moment, the ownership and control rights of the enterprise are still remaining within the scope of blood and marriage relatives.

(3) Pan family business: The pan family business includes not only the family members but also familiar people and relatives in law. The control right of pan family business is possessed by people at the external side of the family. However, the boundary of authorization is critically controlled within a narrow range.

(4) Mixed family business: This type of family business is the mainstream of family business. Mixed family businesses include privately held busi- 
nesses and listed companies. Therefore, the management positions of mixed family business are acted by different identities of management personnel such as the family member, marriage relative, pan family member and familiar people of the enterprise leader and the personnel recruited from the society. The control right of the enterprise is further possessed by people at the external side of the family.

This classification of family businesses reflects greatly the different types of family involvement within the family businesses and facilitates to differentiate the governance of family businesses. However, in assessing family involvement in business, this differentiation can also have some limitations, for example, researchers failed to identify the exact point of deviation from one type of family business to another.

\section{Financial vs Nonfinancial Goals of Family Owned Businesses}

Another approach used to differentiate family versus non family businesses is based on the dimension of different features of family businesses performance measures. Generally, irrespective of the nature of the business, growth performance indicators such as sales and employment growth, and financial indicators in the form of ratios are being used in order to measure the performance in finance of the businesses all over the world. However, it may not be fair to measure performance purely on financial terms. This is because non-financial performance indicators should also be included as many businesses operate towards achieving non-financial goals such as self-satisfaction, business expansion, providing job opportunities, and maintaining the dignity. Such non-financial performance indicators are mostly reflected in family businesses' performance in addition to the financial business performance (Anderson \& Reeb, 2003). 
Naman and Slevin (1993) argue that family businesses need to have a balance between business and family objectives as family business entrepreneurs primarily focus on non financial business performance targets (family objectives) compared to those of non-family. Many research studies emphasize that profit maximization is not the only (or primary) objective of family businesses (Chrisman et al., 2005). They have other broader objectives than profit maximization such as continuing family harmony, maintaining family pride, providing jobs for family members and generational succession (Astrachan \& Shanker, 2003). Such goals may lead even to constraints as they acquire costs which adversely affect business's financial performance (Chua et al., 2006). Even though such non-financial indicators are not limited to family businesses in general, their distinctiveness resides in their objectives; addressing the needs of the family like family control, involvement, reputation, and satisfaction among others.

Present generation that runs the business also matters a lot in case of differentiating family and non family firms in terms of objectives of the business. For instance, Westhed \& Howorth (2006) reveal that first-generation businesses and businesses with a low proportion of managers being family members were less likely to report that family objectives have priority over business objectives. This could be due to some indications that in first-generation family businesses, the owner will probably also be the founder, and issues of survival and growth will dominate in business decisions, while family involvement may be rather limited. As the business matures, the family may turn its attention to support an increasing number of family members in the business (Gersick et al., 1997), and businesses may focus on family objectives to a greater extent than what they were used to do earlier (Dyer \& Handler, 1994).

The real issue more specifically is that whether family business entrepreneurs will place family concerns over business success or growth. Based on this issue, Ward (1987) classifies family businesses depending on their preference to pursue a business-first or a family-first philosophy. 
Dunn (1995) argues that business-first businesses are more likely to possess the attributes needed for growth. Further, Singer and Donahu (1992) identify two distinct types of family businesses: the family-centered business, where the business is a way of life; and the business-centered family, in which business is a means of livelihood.

The discussion in this section suggests that family businesses may create value for the family more than for the business. The performance of family businesses, therefore, is not able to measure totally in terms of financial goals as it is measured in non-family businesses. This mutual interaction between the business and the family cannot be seen in non-family businesses. In such businesses, the ultimate objective could be to maximize profits or achieve financial goals of the firms. Therefore, it can be argued that family businesses are comparatively different from non-family businesses in terms of performance measures, and thus, in measuring the performance of family businesses, non-financial measures need to be considered in addition to the financial measures of performance.

\section{A Framework to Explain the Governance of Family Owned Businesses}

This paper argues that power of the family in family businesses depends on the ownership and the management. The former seems to be based on the ownership share of the family members in business while the latter can be depended on the degree of representation of family members in the board and the team of management. Such factors, together with the experience of the family members in owning and managing the business and the cultural factors, are likely to influence the performance measured in terms of financial and non-financial indicators. Figure 1 shows the diagram of this relationship. In sum, this paper supports the literature that argues "family businesses are comparatively different from non-family businesses" and 
"family ownership and management play a significant role in shaping the family businesses" both of which have an influence on the financial and non-financial goals established by the family businesses.

Figure 1. An analytical model to explain the governance of family owned businesses

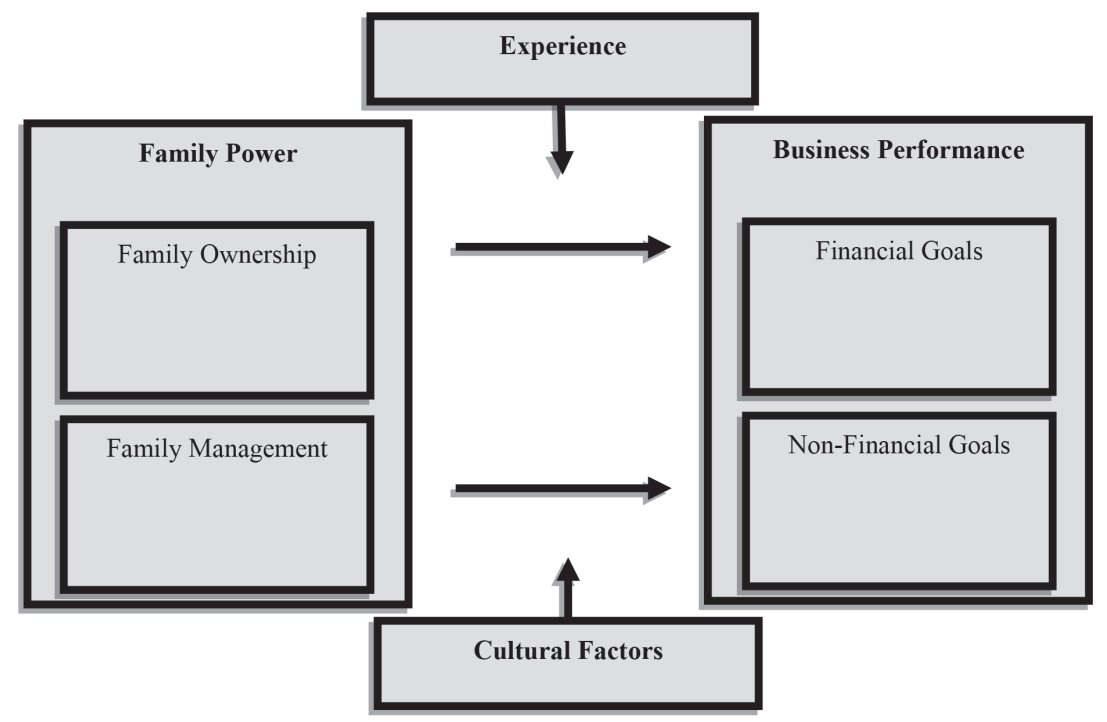

Source: own work.

\section{Concluding Remarks}

This paper reviewed the literature on family businesses. It critically examined the existing definitions on family businesses and discussed different views of family involvement in family businesses in order to identify specific characteristics of family businesses and to assess the ways in which they are different from non-family businesses. Further, family businesses were classified into four groups based on how they are owned and managed in order to identify the differences within the family businesses. Furthermore, it was revealed based on the literature review that the goals of family businesses are different from those of non-family businesses; where in the 
former, non-financial goals are also established in addition to the financial goals. All these findings suggest that family businesses are comparatively different from non-family businesses and family involvement plays a significant role in shaping the degree of success of family businesses. It can be concluded that despite of all different views of definitional, involvement and performance measures, family power, i.e., family ownership and management, are core in the governance of family businesses.

Authors of this article are thankful to University of Peradeniya, Sri Lanka for the Research Grants 2014/2015, 'Governance of Family Businesses in Sri Lanka: Issues and Challenges for Sustain and Growth, for the financial support to carry out this research. 


\section{References}

Alcaraz, J. (2004) Family influence on financial performance satisfaction in Mexican family businesses, Alliant International University, USA.

Anderson, Alistair R., \& David M. Reeb. (2003) Founding family ownership and firm performance: Evidence from the S\&P 500. Journal of Finance, 58, 1301-1327.

Astrachan, J.H., Shanker, M.C. (2003) Myths and Realities: Family Businesses' Contribution to the US Economy-A Framework for Assessing Family Business Statistics. Family Business Review, 9, 107-123.

Astrachan, J., Klein, S., \& Smyrnios, K. (2002) The F-PEC scale of family influence: A proposal for solving the family business definition problem, Family Business Review, 15, 45-58.

Ayranci, E. (2009) The Influence of Family in Family Businesses and Research on its Relationship with Financial Performance Satisfaction, Istanbul University, Turkey.

Ayranci, E., \&Semercioz, F. (2010) Family-Power, experience, culture scale and a research about the relationship between family influence and top managers' view about managers who are family members in the family businesses", Istanbul University Journal of the School of Business Administration, 40, 96-119.

Buckley, J. (2006) Ethical behaviour and family-owned firms: why would I do business with you? Family business from the Irish consumer's perspective. Paper presented at IFERA 6th Annual Research Conference. 22-24 March, 2006. University of Jyvaklyla, School of Business and Economics, Finland.

Chrisman, J.J., Chua, J.H. and Zahra, S.A. (2003) Creating Wealth in Family Firms through Managing Resources: Comments and Extensions. Entrepreneurship Theory and Practice, 27: 359-365. doi: 10.1111/1540-8520.t01-1-00014

Chrisman, J.J., Chua, J.H., \& Sharma, P. (2005) Trends and directions in the development of a strategic management theory of the family firm. Entrepreneurship Theory and Practice, 29, 555-576.

Chrisman, J.J., Kellermanns, F.W., Chan, K.C., \& Liano, K. (2010) Intellectual foundations of current research in family business: An identification and review of 25 influential articles. Family Business Review, 23, 9-26.

Chua, J.H., Chrisman, J.J., \& Steier, L.P. (1999) Extending the theoretical horizons of family business research, Entrepreneurship Theory and Practice, 27, 331-338 
Dharmadasa, P. (2009) Organisational Learning, Innovation and Performance in Family-Controlled Manufacturing Small and Medium-Sized Enterprises (SMEs) in Australia, Unpublished PhD Thesis, Bond University, Queensland, Australia.

Di Pofi, J. (2003) Effects of family influence on satisfaction with financial performance in family businesses, Unpublished PhD Thesis, Auburn University, USA.

Dudaroglu, M. (2008) Relationships among family influence, top management team issues, and firm performance: An empirical study of the automotive supplier industry in Turkey using structural equation modeling, Yeditepe University, Turkey.

Dunn., Barbara., \& Kenneth, K. (1995) The Family Factor: The Impact of Family Relationship Dynamics on Business-Owning Families during Transitions, Family Business Review, 12, 21-41.

Dyer, G.W. (2006) Examining the "Family Effect" on Firm Performance. Family Business Review, 19(4), 253-273.

Dyer, W., Gibb J., \& Handler, W. (1994) Entrepreneurship and family business: exploring the connections. Entrepreneurship Theory and Practice, 19, 71-83.

Gersick, K. E., Davis J., Hampton, M., \& Lansberg, I. (1997) Generation to generation: life cycles of the family business. Boston, Massachusetts Countries, Family Business Review, 16, 269-281.

Goehler, A. (1993) Dissertation, HSG St. Gallen.

Gomez-Mejia, L.R., Nunez-Nickel, N., \&Guiterrez, I. (2001) The role of family ties in agency contracts. Academy of Management Journal, 44(1), 413-435.

Habbershon, T.G., Mary L.W., \& lan MacMillan C. (2003) A unified systems perspective of family firm performance. Journal of Business Venturing, 18, 451-465.

Habbershon, T.G., \& Williams, M.L. (1999).A resource-based framework for assessing the strategic advantages of family firms. Family Business Review, 13(1), 1-25.

Jaskiewicz, P., Gonzalez, V., Menendez, S., \&Schiereck, D. (2005) Long-run IPO performance analysis of German and Spanish family-owned businesses, Family Business Review, 18, 179-202.

Klein, S., Astrachan, J., \& Smyrnios, K. (2005) The F-PEC scale of family influence: Construction, validation and further implication for theory, Entrepreneurship Theory and Practice, 29, 321-39.

Miller, D., \& Isabelle L.B. (2008) Kicking the Habit: Broadening Our Horizons by Studying Family Businesses. Journal of Management Inquiry, 16, 27-30. 
Morck, R., \& Yeung, B. (2004) Family control and the rent-seeking society. Entrepreneurship Theory and Practice, 28, 391-409.

Naman, J.L., \&S levin D.P. (1993) Entrepreneurship and the concept of fit: A model and empirical tests. Strategic Management Journal, 14, 137-153.

Nicholson, N. (2008) Evolutionary psychology and family business: A new synthesis for theory, research and practice. Family Business Review, 21: 103-118.

Paredo, A. (2003) Nothing Thicker than Blood? Commentary on 'Help One Another, Use One Another: Toward an Anthropology of Family Business. Entrepreneurship Theory and Practice, 27, 397-400.

Poza, E.J. (1995) Family Business. Mason, USA: Thomson South-Western.

Sharma, P. (2004) An overview of the field of family business studies: current status and directions for the future. Family Business Review, 17, 1-36.

Sharma, P. (2004) An overview of the field of family business studies: current status and directions for the future. Family Business Review, 17, 1-36.

Singer, J. \& Donahu, C. (1992) Strategic Management Planning for the Successful Family Business, Journal of Business and Entrepreneurship, 4(3): 39 -51.

Stewart, A. (2003) Help One Another, Use One Another: Toward an Anthropology of Family Business. Entrepreneurship Theory and Practice, 27, 383-396.

Ward, J. L. (1987) Keeping the family business healthy: how to plan for continuing growth. San Francisco: Jossey-Bass.

Westhead, P. and Howorth, C. (2006) Ownership and Management Issues Associated With Family Firm Performance and Company Objectives. Family Business Review, 19(4) 301-316. 